\title{
Level of Awareness of Hepatitis 'C' Among Primary Grade: A School Health Intervention
}

\author{
Aneeza Jamshed ${ }^{1 *}$ and Syed Amir Gillani \\ ${ }^{1}$ MBBS Student, King Edward Medical University, Lahore. Pakistan; ${ }^{2}$ Dean Faculty of Allied Health Sciences, The Universi- \\ ty, Lahore, Pakistan.
}

\begin{abstract}
There is a lack of awareness about hepatitis $\mathrm{C}$ due to poverty, involvement of quacks and less penetration of mass media. To develop the awareness of hepatitis $\mathrm{C}$ among primary grade students. A total of 150 students of primary grade among 300, of Government sector Middle School Lahore were selected through multistage cluster sampling. A quasi-experimental study was conducted in the time period of 6 months from April 2014 to Sep 2014. Data analysis was done with SPSS 20. After describing the important variables, average percentages were used to find out the difference between pre and post awareness performances and $\mathrm{t}$ score and $\mathrm{p}$ value was calculated. All the students (150) were boys, $98 \%$ belonged to a lower middle class family with the age of 9-12 years. During pre-testing evaluation, students were never given the knowledge about hepatitis $\mathrm{C}$, its source of transmission (contaminated syringes) and its secondary prevention. Only $3 \%$ knew that it can be prevented. About $61 \%$ thought that it is a disease of adults. Only $21.1 \%$ students thought it can be cured. In post awareness assessment after 3 sessions of interactive learning, 92\% students understood the prevention of hepatitis $\mathrm{C}$ disease, its transmission (syringes 88.7\%, blood transfusion 91\%), signs (effects on liver 92.9\%), symptoms (88\%), prevention in high prevalent areas (sterilized syringes and screened blood transfusion $86.5 \%$ ) and management (88.7\%). This study showed that it may be an important school health based intervention to educate students about the transmission, prevention and management of hepatitis $\mathrm{C}$, which may help in declining the disease burden. Hepatitis C, Unsterilized syringes, Hepatitis C Awareness, Prevention of Hepatitis C.

Received | May 09,2016; Accepted | November 02, 2017; Published |December 20, 2017

*Correspondence | Aneeza Jamshed, MBBS Student, King Edward Medical University, Lahore, Pakistan; Email: aneeza_jamshed@yahoo.com Citation $\mid$ Jamshed, A. And S.A. Gillani. 2017. Level of awareness of hepatitis ' $C$ ' among primary grade; A school health intervention. Annals of King Edward Medical University, 23(4): 445-451.

DOI | http://dx.doi.org/10.21649/journal.akemu/2017/23.4. 445-451.

Keywords | Hepatitis C, Syringes, Diesease, HCV, Pakistan
\end{abstract}

\section{Introduction}

$\mathrm{H}$ epatitis can be due to toxins, viral infection, medication, and alcohol use. ${ }^{(1)}$ Hepatitis due to viral infection is due to coming in contact with any one of these: HAV, HBV, HCV, HDV and HEV. Hepatitis $\mathrm{C}$ is a contagious disease caused by Hepatitis $\mathrm{C}$ virus (HCV). (2) The illness due to hepatitis may be mild lasting for a few weeks or may be severe, serious and life-threatening. Hepatitis $\mathrm{C}$ infection has two main Oct-Dec 2017 | Volume 23 | Issue 4 | Page 445 phases of progression; acute phase and chronic phase. Acute phase hepatitis $\mathrm{C}$ infection can occur during the first six months of the exposure to the Hepatitis $\mathrm{C}$ virus $(\mathrm{HCV}) \cdot{ }^{(3)} \mathrm{As}$ symptoms worsens, following conditions result: Circulation problems, enlarged spleen (mainly in alcoholics), dizziness, drowsiness, hives, itchy skin, yellow discoloration of skin, eyes and conjunctiva, dark urine, light colored feces often with pus. The chronic hepatitis infection occurs after a $\log$ latent period in already exposed persons. 
Annals of King Edward Medical University

About forty percent of infected persons recover fully and out of rest of sixty percent, twenty percent became cirrhotic and twenty percent progress to cancer of the liver. Transmission mainly occurs through the contact with infected blood, invasive procedures of anesthesia due to failure of aseptic measures, sharing needles as in I/V drug abusers, being stuck with needle that had infected blood on it, vertical transmission to an infected mother ${ }^{(4)}$, having sexual contact with an infected person, making tattoos or piercing on the body with unsterilized needles, people who have received blood transfusions due to ineffective screening procedure, ${ }^{(5)}$ using infected/contaminated brushes, ${ }^{(6)}$ infected razors in the barbers shop ${ }^{(7)}$. Liver cancer occurs in $20 \%$ of cirrhotic patients.

According to a research conducted In Lahore, regarding the prevalence of hepatitis $\mathrm{C}$ among general public, in $2013,4.9 \%$ of the 4246 subjects were confirmed to harbor active HCV infections and the "middle aged" population in Lahore was found to be at a higher risk of the HCV ailments compared to both their younger and older peers. ${ }^{(8)}$ Studies conducted previously showed that the percentage prevalence of Hepatitis $\mathrm{C}$ virus in the general adult population was $4.95 \% \pm$ $0.53 \%{ }^{(9)}$. A study conducted in March 2009 in Karachi shows that this recent increase in infection rate is mainly due to increased usage of unsterilized syringes and contaminated razors and instruments. About 2.5 billion syringes are used every year in Pakistan. ${ }^{(10)}$ As a result of study conducted by Malik IA in 1992 in Pakistan, Pakistan has been declared as "cirrhotic state" in international health circle. ${ }^{(11)}$ More than 15 million people have been already infected with Hepatitis $\mathrm{C}$, mainly attributed to reuse of syringes. ${ }^{(12)} \mathrm{It}$ was reported in the research Hepatitis $\mathrm{C}$ virus infected patients have received 5 or more injections in the past 10 years compared to non-infected people. ${ }^{(13)} \mathrm{It}$ was also reported that the household members who have more than 4 injections per year were 119 times more likely to get Hepatitis $\mathrm{C}$ virus infections than others. ${ }^{(14)}$ In a report, injection use is the major mode of transmission of Hepatitis C. ${ }^{(15)}$

In Pakistan, people in the rural area, for face shaving, go to the barber shop, where razors are contaminated razors. ${ }^{(16)}$ In a study it is showed that when military recruits are screened for Hepatitis $\mathrm{C}$ virus before induction; a percent prevalence of $3.64 \% \pm 0.315$ in candidates for military recruitment has been noticed. ${ }^{(17)}$ In an Article in Express Tribune published in July
2015, and article in JPMS cited on July 2011, it is given that among many other causes, Blood Transfusion is also a major cause. Transfusion Authority said that there are over 1,830 blood banks across the country and more blood is used for thalassaemia patients. ${ }^{(18)}$ So blood transfusion can be unsafe if the donors are infected. ${ }^{(19)}$ Of all the causes, the most important one is the lack of education ${ }^{(20)}$ and poverty. ${ }^{(21)}$

The research in Pakistan showed that awareness rate about hepatitis is very low. According to Health ministry Report of 2002, Due to increasing rate of poverty, increasing population, preponderance of unqualified practitioners and less penetration of mass media, there is a rise in spread C. ${ }^{(22)}$ However, no steps have been taken to guide the population regarding the prevalence and mode of transmission of Hepatitis $\mathrm{C}$ virus. ${ }^{(23)} \mathrm{All}$ the previous studies conducted nationally or internationally show that awareness regarding Hepatitis $\mathrm{C}$ disease, its transmission, prevention and treatment among the children as well as adult population is very poor. The importance of my study is to develop the awareness regarding the control of transmission, its prevention and treatment of Hepatitis $\mathrm{C}$ among the school children to lower down the mortality and morbidity among the population at the early stages of ages by intervention, counselling and evaluation session. The awareness is evaluated at primary level because the majority of population of Pakistan is enrolled in education system at primary level.

\section{Material and Methodology}

The study design is Interventional, Quasi-experiment, with a duration of April 2014 to Sep, 2014 (6 months), conducted at Government sector Middle School Lahore primary grade students. Sample size is 150 students and multi stage cluster samplingtechnique was used for the sampling process.

ETHICAL APPROVAL for the study was obtained from institutional review board and record is kept confidential.

Data were collected by researchers with the help of pretested questionnaire (data collection tool). The pretested, validated and specially designed questionnaire was used for collection of our data. Questionnaire included questions regarding general science knowledge of human body, disease, its causation, viruses and knowledge about hepatitis keeping in consideration 
the sociocultural context and psychosocial sensitivity of certain cultural practices. The educational material was specially designed and figures were included for understanding according to the prescribed syllabus of the science of primary grade. Data were collected by researcher team by filling of structured pre-tested questionnaire before and after intervention i-e 3 sessions of interactive learning were arranged with the students. in first session, students were taught about various scientific terms used in questionnaire depending upon their science subject, questionnaire were filled to have pre awareness assessment of their knowledge, their basic knowledge regarding science and disease (hepatitis) was evaluated and they were taught about concept of disease, virus, its transmission, disease causation, and general physiology of body organs. In $2^{\text {nd }}$ session, they were taught about hepatitis, its causation, transmission, signs, symptoms and effects using diagrams drawn on boards.

In $3^{\text {rd }}$ session, they were taught about different common sources of transmission of hepatitis $\mathrm{C}$ in our society (needle abuse, razors and blood contact), ways of prevention (hand washing technique, use of screened blood, disposal of used syringes, qualified dental care) and availability of treatment and referral using brochures and material for health education. At the end of $3^{\text {rd }}$ session, about after 15 days, post awareness evaluation was conducted using the same questionnaires, used in pre awareness testing, to evaluate the net gain in awareness of students.

Data were analyzed using SPSS 20 and interpreted showing difference and net gain in pre and post awareness evaluations using the qualitative variables. Percentage of students giving right answers in pre and post-awareness questionnaires was calculated and compared to get the net increase in awareness in the post awareness evaluation. Probability value and $\mathrm{t}$ - score for independent paired samples was used to calculate the results.

\section{Results and Discussion}

All students participated actively. All the students were boys and $98 \%$ belonged to a lower middle class urban society having monthly income upto 20,000, with houses of 2-3 bedrooms and common bathrooms with mostly joint family systems. All the students were in age group of 9-12 years. Students belonging to Punjabi families were $96 \%$. None of the student knew that hepatitis is a treatable disease. Only 3\% knew that it can be prevented. Most of the students (61\%) also thought that it is a disease of adults and cannot occur in children. None of the students were having knowledge of the availability of screening test for hepatitis C. half (50\%) of the students knew that their hygiene habits have effect on this disease. After awareness session, $97.5 \%$ students became to know that blood test can detect Hepatitis C and $86.5 \%$ became to know that hand washing technique, qualified dental treatment, use of screened blood and disposal of used contaminated syringes is necessary for the prevention of Hepatitis.

The results of important variables of post awareness program calculated as percentages of students who gave correct information on post awareness performas after 3 sessions of awareness programs are (as calculated from data from SPSS variables). (Table 1).

Table 1: Post awareness results.

$\begin{array}{lll}\text { Variable Asked } & \begin{array}{l}\text { \% Of Students } \\ \text { Giving Correct } \\ \text { Answer } \\ \text { (post awareness) }\end{array} & \begin{array}{l}\text { \% Of Students } \\ \text { Giving Correct } \\ \text { answer (pre }\end{array} \\ \begin{array}{lll}\text { Awareness of disease } \\ \text { HEPATITIS }\end{array} & \begin{array}{l}\text { 9w.9\% } \\ \text { Transmission by environ- }\end{array} \\ \begin{array}{l}\text { ment } \\ \begin{array}{l}\text { Spread By shaving razors } \\ \text { and needles }\end{array}\end{array} & 86 \% & 38.7 \\ \begin{array}{l}\text { Spread With blood trans- } \\ \text { fusion }\end{array} & 91 \% & 50 \% \\ \begin{array}{l}\text { Sign and symptoms } \\ \text { Effect of Hepatitis C on } \\ \text { liver }\end{array} & 90.5 \% & 28 \% \\ \begin{array}{l}\text { Shaving razors and re used } \\ \text { syringes a major cause }\end{array} & 94.3 \% & 71.5 \% \\ \end{array}$

Graphical representation of net increase in awareness by combining data from pre and post awareness forms (Figure 1)(Figure 2)(Figure 3) (Table 2).

Different awareness studies conducted in Pakistan and internationally are only observational, evaluating the present knowledge of adult population about hepatitis $\mathrm{C}$, neither of these studies involved intervention and awareness programs to estimate the increase in knowledge of adults after $i^{(24)}$. So my study is almost innovative according to my topic as it included the evaluation of effectiveness of the awareness programs and the intervention in the form of awareness sesOct-Dec 2017 | Volume 23 | Issue 4 | Page 447 
sions and evaluation of these programs. So my discussion will only be comparing the results of pre and post awareness evaluations conducted in the school children.

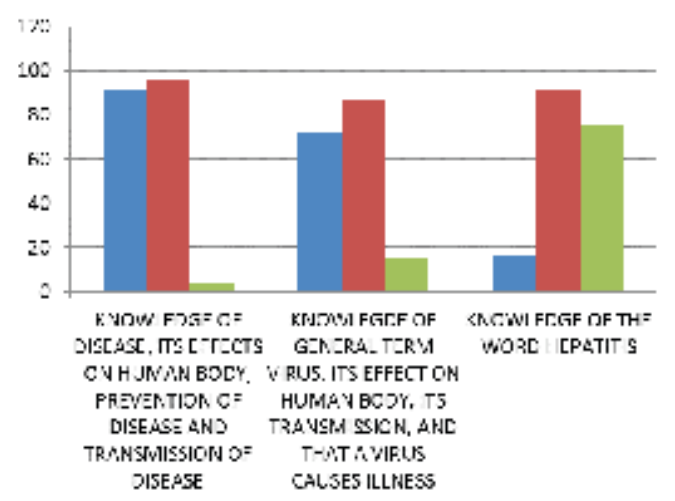

Figure 1: Results of general awareness.

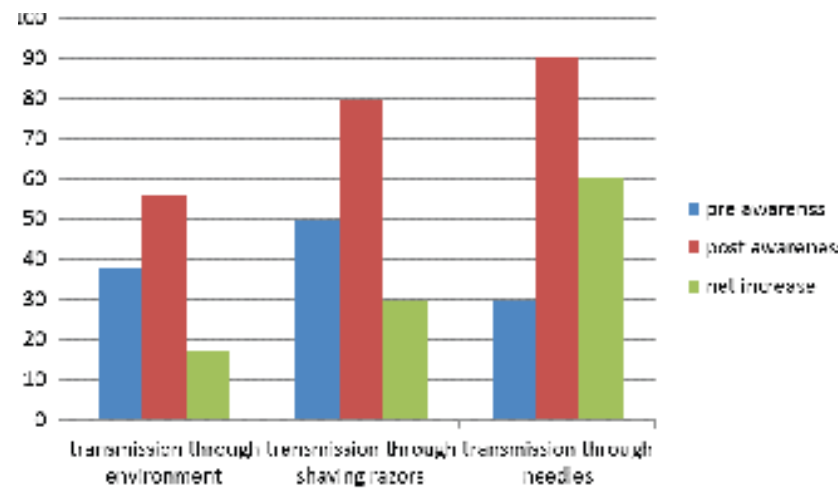

Figure 2: Results regarding transmission factors.

The major reason behind the students already having a brief knowledge of body organs and some diseases was, there is science subject being taught at the school level right from the beginning and various preventive programs like dengue program have been initiated in this area resulting in improving the basic knowledge of the students.

About $91 \%$ students already had a concept of process of disease causation, effects and transmission through micro-organisms. This ratio enhanced to $96.5 \%$ after 1 session of class on general process of disease phenomenon. About $72 \%$ of the students had the knowledge about viruses, life cycle, effects on human body and diseases most commonly caused by the viruses. This ratio increased to $87.7 \%$ after 1 session of class. According a study conducted on adult population, in Mansehra $11.4 \%$ people never heard of Hepatitis $\mathrm{C}^{(25)}$. At the level of primary school, due to various health program initiatives involving school level teachers in Punjab, about $92.5 \%$ already have heard about hepatitis

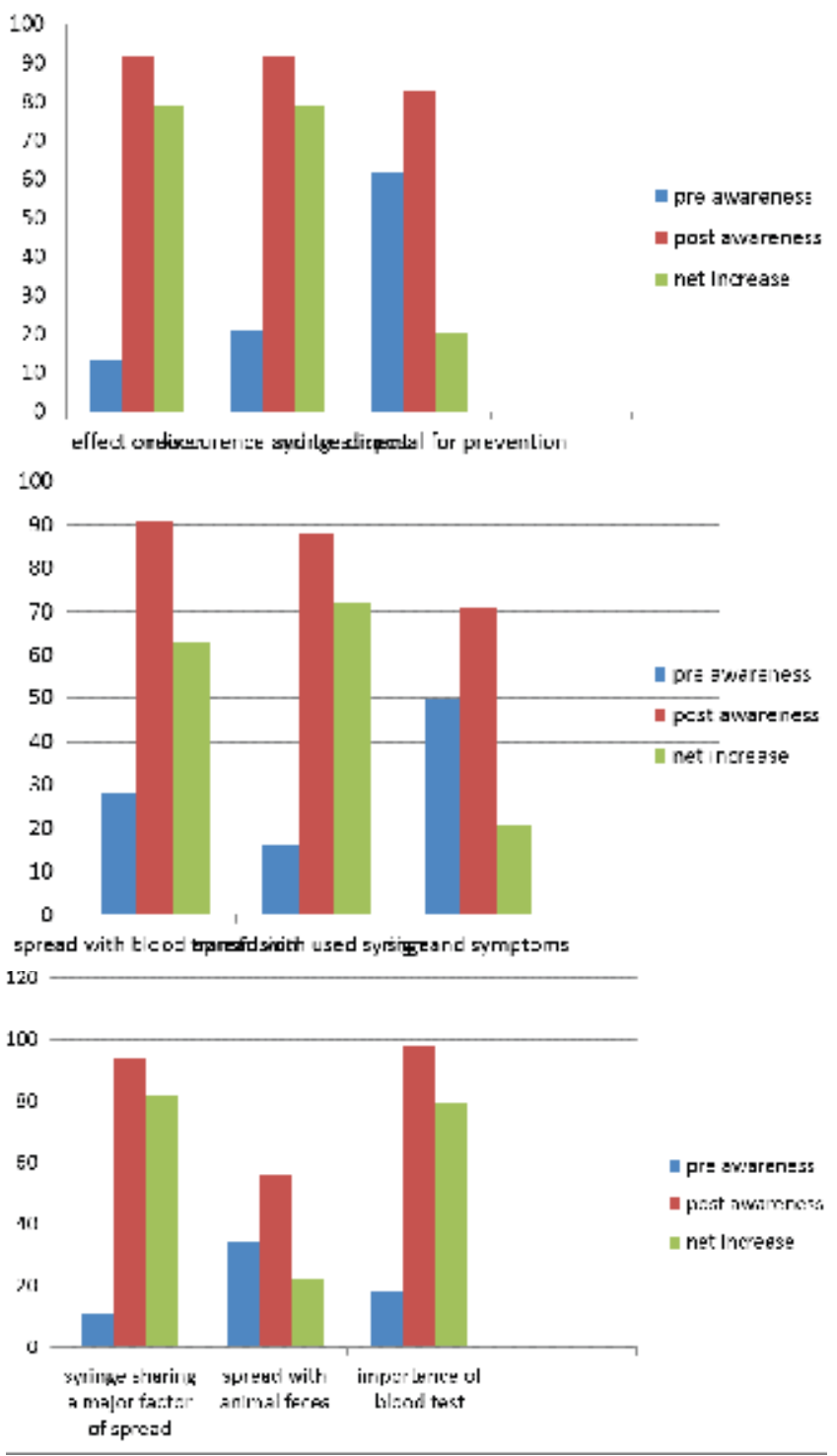

Figure 3: Results of awareness of preventive measures.

C disease through various sources of television, parents, books, news and teacher. The highest ratio of students heard it from their teachers, i-e 76\% and the lowest number of students' i-e 29\% heard it from television and news.

According to the study in Adults, 27.5\% completely have no idea of transmission of hepatitis C, only $72 \%$ were aware of its transmission by contaminated blood, $13 \%$ by sexual contact and $35.9 \%$ by tooth brushes. In another study in Egypt, 52\% adults didn't know what causes an infection, $42 \%$ knew about viruses with incorrect modes of transmission of Hepatitis $\mathrm{C}$ and 30\% didn't know the disease signs and symptoms. Whereas in our study, A brochure provided by AAPNA regarding the sign and symptoms and prevention was used to teach students about hepatitis C. 
Table 2: Comparison of pre and post awareness about Hepatits $C$.

\begin{tabular}{|c|c|c|c|c|}
\hline \multirow[t]{2}{*}{ Variables } & \multirow{2}{*}{$\begin{array}{l}\text { Pre Awareness Result }(\mathrm{X}) \\
\% \text { Of students with correct } \\
\text { answers }\end{array}$} & \multirow{2}{*}{$\begin{array}{l}\text { Post Awareness Result (Y) } \\
\% \text { of students with correct } \\
\text { answers }\end{array}$} & \multicolumn{2}{|c|}{ Net Improvement } \\
\hline & & & $\mathrm{X}-\mathrm{Y}$ & $(\mathrm{X}-\mathrm{Y}) 2$ \\
\hline Knowledge Of Disease & $\begin{array}{l}96.5+98.5+96.5+75.4 / 4 \\
=91.75 \%\end{array}$ & $\begin{array}{l}97.9+98.5+96.5+92.9 / 4 \\
=96.5 \%\end{array}$ & $-4.75 \%$ & 22.56 \\
\hline Knowlegde Of Virus & $\begin{array}{l}87.3+55.6+53.3+92.9 / 4 \\
=72.28 \%\end{array}$ & $\begin{array}{l}95+92+67.67+96.5 / 4 \\
=87.79 \%\end{array}$ & $-15.51 \%$ & 240.5 \\
\hline Knowledge Of'The Hepatitis & $16 \%$ & $92.9 \%$ & $-76.9 \%$ & 5913.61 \\
\hline \multicolumn{5}{|l|}{ Transmission Of Hepatitis Through: } \\
\hline 1: Environment & $38.7 \%$ & $56 \%$ & $-17.3 \%$ & 299.29 \\
\hline 2: Shaving Razors And Neeedles & $30 \%$ & $90 \%$ & $-60 \%$ & 3600 \\
\hline 3: Blood Transfusion And Syringes & $28 \%, 16 \%$ & $91 \%, 88 \%$ & $\begin{array}{l}-63 \% \\
-72 \%\end{array}$ & $\begin{array}{l}3969 \\
5184\end{array}$ \\
\hline Signs And Symptoms & $50 \%$ & $71.5 \%$ & $-21.5 \%$ & 462.25 \\
\hline Effect On Liver & $13 \%$ & $92.9 \%$ & $-79.9 \%$ & 6384 \\
\hline Treatment & $21.1 \%$ & $92.9 \%$ & $-71.8 \%$ & 5155.24 \\
\hline Syringes Disposal For Prevention & $62.7 \%$ & $83.6 \%$ & $-20.9 \%$ & 436.81 \\
\hline $\begin{array}{l}\text { Syringes Sharing A Major Cause } \\
\text { Of Spread }\end{array}$ & $11.3 \%$ & $94.3 \%$ & $-82.7 \%$ & 6839.29 \\
\hline \multirow[t]{2}{*}{ Importance Of Blood Test } & $18.5 \%$ & $98.6 \%$ & $-79.5 \%$ & 6320.25 \\
\hline & & & $=665.76$ & $=44826.49$ \\
\hline
\end{tabular}

T score: 3.1445; Degree of freedom: 149; Significance level: $0.05 ; \mathbf{P}$ value: 0.001004 (the result is significant if $p<0.05$ ) as calculated by epi-info software.

About $50-70 \%$ students knew hepatitis C like other viral diseases also spreads by contact, coughing, fast food, environment, syringes and blood products, but after teaching session, about $88 \%$ came to know that hepatitis $\mathrm{C}$ is specifically also caused by using reused or blood stained syringes as in drug abuse and hospitals. $83 \%$ came to know that blood transfusion has a specific role in the spread of hepatitis $\mathrm{C}$ where as previously $71 \%$ knew that disease spreads with blood but having no specific knowledge regarding hepatitis $\mathrm{C}$ and $90 \%$ became aware of the fact that sharing injections and tooth brushes contribute towards spread of Hepatitis $\mathrm{C}$ due to blood staining and bleeding gums.

About 50\% knew the common and specific symptoms that occur in Hepatitis $\mathrm{C}$, this ratio increased to about $80 \%$ awareness program. $92 \%$ successfully understood that hepatitis $\mathrm{C}$ is the disease affecting liver. Another $76 \%$ had an understanding that hepatitis $\mathrm{C}$ may be a treatable disease but still $85 \%$ thought that it is a fatal disease. After awareness program, the ratio of students knowing that hepatitis $\mathrm{C}$ is a completely treatable disease increased to $91.5 \%$.

In the present situation of health system of Pakistan, most of the people due to lacking education, oblivious attitude and various spiritual treatment systems shirk from going to hospitals for their illness. The awareness program led to net total of $95 \%$ students believing that it is necessary to go the hospital and doctor for medication for the illness caused by hepatitis C. About $98.6 \%$ of the students became to know that there is a specific blood test for the detection of hepatitis $\mathrm{C}$ as compared to the $68.8 \%$ of population knowing about the specific testing in study conducted in adult population.

Through interactive session with the students, about $75 \%$ learned that maintaining personal hygiene can prevent the spread of hepatitis $C$. The limitation of our study is that we couldn't arrange sessions with the teachers and the parents regarding the spread and prevention of Hepatitis C. we also couldn't compare the effect of awareness program among students of different areas and rural and urban society.

\section{Conclusion}

Our study showed that students at primary standard level can be involved in the awareness of preventive 
Annals of King Edward Medical University

measures using interactive sessions and tests ensuring their full participation and practical application of the knowledge.

According to the present situation of increasing hepatitis $\mathrm{C}$ cases in Pakistan, it is found necessary to educate students about the transmission, prevention and treatment of hepatitis C. not only this but they can also be taught about other communicable diseases in our society and not only students but their teachers and parents can also be involved in awareness, prevention and control program. All the students were found to have a sound basic knowledge of human body and its relationship to various diseases because of the subject of science that is taught at school level. So if the students are comprehensively taught, curriculum and education system may produce significant results towards decreasing the morbidity and mortality due to hepatitis $\mathrm{C}$ and other epidemics.

\section{Author Contribution}

Aneeza Jamshed: Data Collection, Analysis, Sypnosis, Abstract Formation, Results.

Syed Amir Gilani: Substantial contribution to conception and design, Acciqusition of data, Analysis and intrepretation of data.

\section{References}

1. Kumar V, abbas AK, Fauster N, Aster TC. Robbins basic pathology. Ed $8^{\text {th }}$, China: Saudder Elsevier; 2010:pg 641-646

2. Kumar V, abbas AK, Fauster N, Aster TC. Robbins basic pathology. Ed $8^{\text {th }}$, China: Saudder Elsevier; 2010:pg 641-646

3. Parker SP, Khan HI, CubittWD.Detection of antibiodies to hepatitis $\mathrm{C}$ virus in dried blood spot samples from mother and their offsprings in Lahore Pakistan. J clin Gstroenterology. 2001;33:407-411[ PMC free artice] [Pub med]

4. Ahmad, K., et al., Novel means of spread of bloodborne infections in Pakistan. Lancet, 2004.363(9425):p.2002

5. Ministry of Health, Annual report. ,Director General health, Government of Pakistan. 200102

6. M. Ryas, T. Hussain, F.A. Bhatti, F. Ahmed, W.Uz Zaman Tariq, M.F. Khattak. Epidemiology of hepatitis $\mathrm{C}$ viru infections in blood donors in Northern Pakistan. J Rawalpindi Med college,
2001; 14: pp. 56-59

7. Anwar M, Rahman M, Hassan M, Iqbal M. Prevalence of active hepatitis $\mathrm{C}$ virus infections among general public of Lahore, Pakistan. Virol J. 2013; 10(1):351 https://doi.org/10.1186/1743422X-10-351

8. Raja NS, Janjua KA. Epidemiology Of hepatitis In Pakistan. J Microbial Immunol infect 2008; 41:4-8

9. Malik I.A., Et al., Hepatitis $\mathrm{C}$ as a cause of chronic liver disease in Northern Pakistan. JPak Med Assoc, 1992. 42(3):p.67-8

10. Khan AJ. Luby SP. Fikree, F.et al. Unsafe injections aid the transmission of hepatitis $\mathrm{B}$ nd $\mathrm{C}$ in a periurban community, Karachi. Bull.Who., 2000:78: 949-1066

11. Khan AJ. Luby SP. Fikree, F.et al. Unsafe injections aid the transmission of hepatitis $\mathrm{B}$ nd $\mathrm{C}$ in a periurban community, Karachi. Bull.Who., 2000:78: 949-1066

12. Luby Sp. Qamarudin K, Shah AA, Omair , Pasha $\mathrm{O}$, Khan AJ, et al,. The relationship between therapeutic injections and high prevalence of hepatitis $\mathrm{C}$ infection in Hafizabad, Pakistan.Epidemiol Infect 1997; 119:349: 349-56 https://doi. org/10.1017/S0950268897007899

13. Pasha O,Luby SP, Khan AJ, Shah AA, McCromick JB, Fischer-Hoch SP.Household members of hepatitis /c virus infected people in Hafizabad, Pakistan:infection by injection from health care providers. Epidemiol Infect.1999;123:515-518 https://doi.org/10.1017/S0950268899002770

14. Umar M, Bushra H, et al.Hepatitis C in Pakistan: A review of data available. Hepatitis Monthly 2010;10:20-214

15. Ban A, AKhtar S. Rahbar MH, et al. Risk factors of hepatitis $\mathrm{C}$ virus infection in male adults in Rawalpindi-Islamabd Pakistan. Trop Med mt Health 2001:6:73-8

16. Mirza IA, Mirza SH, Irfan S, Siddiqi R, Tariq WZ, Janjua AN, seroprevalance of hepatitis $B$ and $\mathrm{C}$ in young adults seeking recruitments in armed forces. Pak Armed forces Med J 2006:56:192-7

17. The Express Tribune. number of hepatitis $c$ cases rising in pakistan, falling in other developing countries. [Internet]. 2014 [cited 8 July 2015];:single. Available from: http://tribune.com. $\mathrm{pk} /$ story/777637/number-of-hepatitis-c-cases-rising-in-pakistan-falling-in-other-developing-countries/

18. The Express Tribune. number of hepatitis c 
Annals of King Edward Medical University cases rising in pakistan, falling in other devel- 21. Alam M, Tariq WZ. Knowledge attitudes and oping countries. [Internet]. 2014 [cited 8 July 2015];:single. Available from: http://tribune.com. $\mathrm{pk} /$ story/777637/number-of-hepatitis-c-cases-rising-in-pakistan-falling-in-other-developing-countries/

19. A Silent Storm: Hepatitis C in Pakistan. JPMS [Internet]. 2011 [cited 8 July 2015];1(3):89-91. Available from: http://www.jpmsonline.com/ jpms-vol1-issue3-pages89-91-pa.html

20. A Silent Storm: Hepatitis C in Pakistan. JPMS [Internet]. 2011 [cited 8 July 2015];1(3):89-91. Available from: http://www.jpmsonline.com/ jpms-vol1-issue3-pages89-91-pa.html practices about Hepatitis $\mathrm{B}$ and $\mathrm{C}$ among young healthy males. Pak J Pathol 2006;17(4):147-50.

22. Hamid S, Umar M, Alam A, Qureshi H, Butt J, Member of consensus Panel (2003). PSG consensus Statement on Management of hepatitis $\mathrm{C}$ virus infection. The J Pak Med Assoc,54(3):146-150. [Pub Med]

23. Saleha DA, Amr S, JIlson IA et all.Knowledge and perception of Hepatitis $\mathrm{C}$ infection and pesticides uses in two rural villages in Egypt. BML Public Health 2014;15:501. https://doi. org/10.1186/1471-2458-14-501 